\title{
EVALUATING THE EFFECTIVENESS OF AN ACADEMIC LITERACY COURSE: DO STUDENTS BENEFIT?
}

Jean Parkinson, Leonora Jackson, Tamlin Kirkwood \& Vasanthie Padayachee University of KwaZulu-Natal

The proliferation of academic literacy courses in South African universities in the last 25 years prompts the question of how effective such courses are. Addressing the difficulties of studying in a second language combined with insufficient stress on reading and writing at school, such courses are designed to assist students with university reading and writing tasks. This article describes how reading and writing acquisition are scaffolded in one such course designed specifically for students who enter a science degree programme through alternative access routes. It then assesses how successful the course is at improving students' academic reading and writing. Equivalent tests before and after the course indicate that students do improve their academic reading and writing, with the weakest students making the biggest improvement. By the end of the course the academic literacy of this weakest group is, however, still not equivalent to that of regular entrants to the Faculty. Student evaluation at the end of the course indicates that students believe they have learnt much from the course and, to a lesser extent, that they have enjoyed the course. Previous students report making extensive use of the literacies taught by the course in the later years of their degrees.

Keywords: academic literacy, scaffolding, course assessment, success, effectiveness

\section{INTRODUCTION}

The area of academic literacy, the ability to write in the expected discipline-specific ways, has grown at South African universities in the last 25 years. This coincides with changes in the student intake at South African institutions to include students who may have attended schools which provided inadequate opportunities for writing and reading. The question of whether academic literacy courses are effective, raised by Van Dyk (2005), is thus important. In this article we consider Communication in Science, an academic literacy course for science students, and test whether the course has reached some of its outcomes: improving the students' academic reading and writing. We use three means of assessing this. Firstly we test the students by means of initial and terminal tests of reading and writing. Secondly, we draw on student feedback at the end of the course, and finally we consider the feedback of students who did the course in previous years.

In order to situate our course within academic literacy in South Africa, we begin this article by surveying academic literacy development in South Africa over the past few decades. We then move on to describe briefly the particular features of our course, before evaluating its 
effectiveness in improving students' abilities to read and write for academic purposes in the ways mentioned above.

\section{ACADEMIC LITERACY DEVELOPMENT IN SOUTH AFRICA}

Traditionally viewed as the ability to read and write, literacy has more recently been viewed by the new literacy theorists (e.g. Street 1984, 1993) as 'multiple' in the sense that reading and writing is used for a wide range of different purposes. These different purposes have a wide range of different behaviours, different literacy events (e.g. the job application letter, speech to introduce a speaker, news article etc.), and different value systems associated with them. Even academic literacy, which is a more restricted notion than literacy as a whole, and might thus be expected to be clearly one thing, is, as we outline below, interpreted differently by different groups.

Starting in the 1980s, the growth of academic literacy as a discipline at South African universities in the last 25 years coincided with universities opening up to educationally disadvantaged students, usually first language speakers of African languages (Starfield, 1994; Yeld \& Haeck 1997; Mabokela 1998).

In addition to the difficulties associated with doing a degree in a second language, many students have attended schools which place little stress on reading and writing (Taylor \& Vinjevold, 1999; Probyn, 2006). For example, Pile \& Smythe (1999) found that schools in their study had textbooks, but that teachers did not issue these to pupils. Pile \& Smythe (1999) speculate that teachers' content knowledge is inadequate for them to understand the textbooks. However, because this lack of use of textbooks is found even in primary schools, another possible explanation is that teachers feel that English textbooks will not be much use to learners whose proficiency in English is very limited. Compounding this is the fact that from an early age pupils have inadequate access to books either in their mother tongue or English (Pretorius \& Matchet, 2004a). The PIRLS study (Mullis, Martin, Kennedy \& Foy, 2007) found that South African primary school learners performed worst out of 40 countries (including other African and developing countries) in reading ability. Written work in schools emphasises copying from the blackboard rather than pupils writing their own texts. Teachers themselves may have limited literacy (Pretorius \& Matchet, 2004b). In these circumstances, the development of Cognitive Academic Language Proficiency (CALP) (Cummins \& Swain, 1986) in either mother tongue or English is difficult and a high proportion of South African students enter tertiary study with inadequately developed reading and writing skills in any language (Clarence-Fincham, 2000).

This situation makes South Africa unusual. In the UK or Hong Kong the growth in English for Specific Purposes and English Language Teaching courses serves very different groups of students who already have well-developed CALP in their own languages. In a different tradition, in the US, there is a long history of writing courses for regular entrants into university, who are first language speakers of English.

There is a wide variety of academic literacy interventions in South Africa and this variety is reflected in three aspects: what the intervention stresses (e.g. grammatical correctness, reading and writing, etc.), mode of delivery or nature of the intervention (whether mediated by consultants or accredited courses of various kinds), and thirdly, how discipline-specific the intervention is with regard to content and genre. 
A stress on grammatical correctness was popular in South Africa in the early years of academic literacy, and is still the focus of some courses; however, in line with a world-wide de-emphasis on explicit grammar teaching, more recently this has changed, perhaps in recognition that speakers of English as a first language are a small minority in South Africa, and that in this context, stressing grammatical correctness rather than meaning may have limited effect and be alienating for students (De Kadt \& Mathonsi, 2003).

Mode of delivery of academic literacy is typically tutorials in a credit-bearing course but individual voluntary consultations at a Writing Centre (e.g. Hutchings, 2005) are also available at many institutions. These consultations may be offered by dedicated writing specialists or by senior students in the discipline.

With regard to the importance given to content and genre, some academic literacy courses (e.g. Van Wyk, 2002) are generic in the sense that they do not focus on a particular content area, because they serve students from a wide variety of disciplines; generic courses often focus on texts which are, of necessity, relatively general in nature, and on teaching students to write essays. Increasingly however, academic literacy courses recognise literacy as differing between disciplines. Such courses, influenced by research in English for Specific Purposes and the growth of the study of genre, are based on the content of particular disciplines, and focus on the favoured genres of the disciplines (e.g. Goodier \& Parkinson, 2000; Pienaar, 2005).

In other cases academic literacy elements are embedded in 'core' courses set up to teach a range of skills (including, for example, problem solving or communication in the workplace). Examples of such courses are those for Engineering students (e.g. Butler \& van Dyk, 2005) and Commerce students (e.g. Goodier \& Parkinson, 2005).

An interesting trend is the building of academic literacy into existing 'content' courses, where literacy specialists work with regular lecturers to extend these courses to include, or make explicit literacy work (e.g. Jacobs, 2005). The approach counteracts the temptation to remove tasks requiring academic literacy (e.g. the replacement of essays with multiple choice questions) because of growth of student numbers or because the changing student population is seen as unable to cope with such literacy tasks.

Academic literacy interventions are largely at first-year or foundational level but there is a growing need for them at post graduate level (e.g. Henning, Maimane \& Pheme, 2001; Henning \& van Rensburg, 2002; Thomson, 2005), particularly in coursework masters courses.

\section{ACADEMIC LITERACY IN SCIENCE}

Acquiring academic literacy in science involves 'learning to communicate in the language of science and act as a member of the community of people who do so' (Lemke 1990:1). Communication in Science, which we describe in greater detail in Parkinson et al. (2007), sets students on the path to acquisition of this literacy by providing opportunities to communicate in science by engaging with science texts and producing new science texts, and by acquiring the behaviour and values of science through collecting, analysing and writing about real data.

To develop the advanced reading and writing skills comprehended in academic literacy, students need to develop a range of abilities including skimming, scanning, making 
inferences, drawing conclusions, reading for main ideas, summarising, analysing and evaluating (Carrell, 1991:160-161) and drawing on their background knowledge to access text (Grabe, 1988:57). They also have to develop skill in noticing and using linguistic clues in a text in order to make meaning. The cognitive academic language proficiency that develops as a result of being exposed to written language enables learners to understand and learn from print information on their own (Pretorius, 2002:99).

In addition, as Rose, Lui-Chivizhe, McKnight and Smith (2003) note, in academic text, language patterns are specialised and involve abstract concepts and discipline-specific technical terms. We show below how we assist students to unpack these specialised language patterns including, in science, a reliance on nominalisation and relatively passivised language.

Academic writing includes the ability to master the favoured genres of the discipline and to adhere to acceptable conventions, as well as the ability to develop and sustain an argument. Students need to be able to identify relevant information and organize it in a coherent way. Because textbooks are the principle reading assigned to science students (Jackson et al., 2006), and laboratory reports the principal kind of writing (Braine, 1989), it is essential that these genres be prominent in an academic literacy course for science students. As discussed above, our students have limited experience of text of any kind. Therefore, there is great value in explicit teaching of the important features of a genre.

\section{A BRIEF DESCRIPTION OF COMMUNICATION IN SCIENCE}

Communication in Science, the course evaluated in this article, is a stand-alone accredited course based in science content. It is offered for the most part to second language speakers of English who enter the Faculty through alternative routes, having attended a school assessed by the Education Department as educationally disadvantaged. The strength of this model is that materials can be carefully designed to rehearse the significant written genres expected of a science student (laboratory reports and essays) while drawing on texts appropriate both in level and genre. Issues of language (such as sentence structure, or the use of the passive voice) can be integrated into content-based work, as can summarising, note-taking, paragraph construction etc. Acquisition of the multiple elements of academic literacy proceeds through an iterative process of reading, writing and analysis on the part of students. Teaching can proceed at a rate appropriate to student needs rather than being driven to move on to cover the content in the curriculum as happens in most university courses. Since academic literacy staff mark repeated drafts, they are able to pay attention on an individual basis and can thus assist students in improving features such as organization and the discourse features of target forms.

These elements of the course reflect the scaffolding process, in which a teacher supports a student in an apprenticeship-like relationship, helping them do what they cannot yet do unassisted (Mercer, 1995). Through modelling, offering advice, or guiding with questions, the teacher supports acquisition of new competencies. As the student becomes more able to do a task, the support is gradually withdrawn (Donato, 1994). Unsworth (1997) and Rose et al. (2003) view scaffolding as an effective way of helping students to read authentic texts required for degree study, while building their confidence in their ability to deal with texts beyond their independent reading ability level. Marking of drafts supports the achievement of a more polished and better organised piece of writing, which is more complete as an answer to a focused question than they could produce unaided. 
Communication in Science itself and how it scaffolds acquisition of academic literacy in science is described in much greater detail in Parkinson et al (2007). For clarity, however, we summarise briefly how the course scaffolds literacy acquisition before moving on to an evaluation of the effectiveness of the course.

Table 1: $\quad$ Examples of some Communication in Science topics

\begin{tabular}{|c|c|c|}
\hline Topic and genre & Sources & Literacies which are the focus of each topic \\
\hline $\begin{array}{l}\text { A laboratory } \\
\text { report on mixing } \\
\text { water of different } \\
\text { temperatures }\end{array}$ & $\begin{array}{ll}\text { Extracts } & \text { from } \\
\text { textbooks } & \end{array}$ & $\begin{array}{l}\text { - } \quad \text { Design and conduct an experiment } \\
\text { - } \quad \text { Record measurements as tables and graphs } \\
\text { - Learn and use the features of the different } \\
\text { parts of the Report genre }\end{array}$ \\
\hline $\begin{array}{l}\text { Essay on Malaria } \\
\text { and how to } \\
\text { combat it }\end{array}$ & $\begin{array}{l}\text { Popular science } \\
\text { articles, } \\
\text { rewritten in } \\
\text { textbook style }\end{array}$ & $\begin{array}{l}\text { - Analyse focused topic and plan own writing } \\
\text { - Read and take notes from written sources } \\
\text { - Integrate information from different sources } \\
\text { - Referencing }\end{array}$ \\
\hline
\end{tabular}

Materials in Communication in Science are organised into topics in four different genres: report, essay, oral presentation and poster. Table 1 outlines the topics, source materials and literacies that we aim to teach in two such topics. In this course, acquisition of academic literacy is scaffolded through:

- Provision of readings appropriate in terms of level and genre

- Terminal questions to test and prompt comprehension

- Practice in methods of gathering, synthesising and organising material for writing

- Multiple opportunities to submit drafts of writing

Most of our students are slow readers, reading at an average reading speed of 100 words per minute (Kirkwood, 2007). Complex syntax, too high a frequency of new words, or material that is conceptually outside students' range of experience can have the effect that students do not do assigned reading. Reading, therefore, has to be both accessible in content and appropriate in genre. As indicated above, the reading that science students are assigned is largely from textbooks, while the writing they are assigned is laboratory reports, factual essays and 'short answers', the last particularly prominent in exams. It is therefore wise to limit assigned reading to the textbook genre, supplemented by the few accessible research articles (these have similarities to the laboratory report) that we can find, or research articles revised to the appropriate level.

Texts are selected from high school or first year textbooks. However these often need reworking, involving limiting difficult vocabulary (whether academic, technical or 'everyday'), providing footnotes to gloss difficult words or references to unknown places, concepts or things, substituting local examples and generally shortening and simplifying the text. Simplified research articles, organised in the Introduction-Method-Results-Discussion form, act as a valuable model for students' own report writing.

Comprehension of academic reading is one of the literacies we test in the initial and terminal tests, discussed in more detail below. To enhance understanding, and to prepare students for reading a text, we use the following strategies, which we hope students will use automatically when reading later texts on their own.

- Initial class discussion on a topic to encourage use of existing knowledge. 
- Pre-reading activities (such as skimming for overall meaning) or an initial brief summary of the text also develop existing frameworks (Kirkwood 2007).

- Reading the first or a key paragraph aloud before scaffolding and unpacking meaning in it (Rose et al., 2003).

These strategies all provide a frame of reference for students for what they will read or reinforce an existing frame of reference, and key words and phrases, on which much textual meaning is built, are rehearsed in more everyday terms. Comprehension questions provide strategies that we hope can be used with later reading, as students question, and puzzle over meaning for themselves. Students may be asked to insert subheadings into texts, alerting them to textual structure, and benefiting their own writing abilities.

Writing an answer to a focused question using information gleaned from more than one text is also tested in the initial and terminal tests in the course. To prepare students for writing, we teach strategies such as analysing a focused question, thinking carefully about what the questions demands before embarking on writing. Students construct a plan, take point-form notes from a number of sources, and organise their ideas using a mind-map. This assists them in avoiding direct copying from the text as well as in organisation. Summarising, paragraph construction and linking paragraphs are also taught.

We aim to provide opportunities for students to practise the important pedagogical genres in science: lab report, essay and poster. We follow Swales's (1990:58) view of genre as a 'class of communicative events, the members of which share some set of communicative purposes which are recognised by the expert members of the parent discourse community'. These communicative purposes are reflected in structure, style, content and intended audience. Vocabulary, grammar and discourse structure of a genre are restricted, and the expert members of the discourse community understand the communicative purposes of their favoured genres well and use them for their own purposes (Bhatia 1993:15). This makes it important for students to have access to and practice their disciplines' favoured genres.

We favour a process approach to the extent that a first draft of any assignment is marked and tutor's comments guide students to improve their writing, including content and organisation of students' writing. These comments may be followed up with consultation with students. The written comments and consultations scaffold student revision of work. They also, it is hoped, get students used to the process of revising their writing, even in later years, once this scaffolding process has been withdrawn. Crouch's research (2006) with students at our institution indicates that students find draft-response-redraft approach beneficial; Crouch judged the process to be helpful as long as staff and students share an understanding of academic discourse, and the cultural values and identity of students are given value to avoid alienating students.

\section{EVALUATING THE EFFECTIVENESS OF THE COURSE}

Many South African universities have developed selection and placement tests (see Yeld 2003; van Dyk 2005; van de Slik \& Weideman 2005; Anthonissen 2006) to admit students whose possible ability to succeed may not be reflected in their school leaving results. A placement test was used to assess students' academic literacy ability at the beginning of the course, and at the end of the course a similar, equivalent test was used to reassess their ability. A second means of evaluating the course was evaluation questionnaires to determine the 
students' perceptions of the course and whether it met their needs. A third means of evaluation was a survey of students who had completed the course in previous years to determine retrospectively whether students found that the competencies they had acquired were indeed valuable in later study of scientific disciplines.

\section{The effectiveness of the course as measured by the initial and terminal tests}

Because developing academic literacy is a complex process, involving socialising into a discourse, acquiring conventions and exposure to appropriate texts, it is hard to assess the Communication in Science course directly. To assess student improvement in the course, two themed standardised tests were used: one before and another at the end of the Communication in Science course. Although not identical, the two tests are based on the same construct and test the same range of competencies in a similar way. The tests do not assume prior knowledge of the topic, and instead provide relevant information (Yeld, 2003). Both tests provide several texts with multiple choice questions based on these texts. The questions attempt to measure ability to read for meaning, extrapolation and application, inferencing, ability to separate the essential from the non-essential and similar aspects of reading. These are key abilities that the course attempts to teach. Both tests include an extended writing task based on extracting and interpreting information from texts to provide a written answer to a focussed question, literacies emphasised in the course. Each test also has a cloze question tapping into a more general proficiency in English. The score of the cloze questions is included in the total percentage of each test in the tables below, but is not reflected in a separate column in table 3 . The texts used are not strictly science-based texts of the type used in the course, but students need analytical reading skills suitable for a wide range of academic texts to interpret them.

Our understanding of academic literacy has influenced the testing tools we used. In line with Weideman (2003), these tests are based on the understanding that language is more than the parts it is composed of (grammar, vocabulary, sound) and more than the skills through which competence is displayed (listening, speaking, reading and writing).

To avoid the possibility of test practice effect, different tests are used to evaluate progress. Both tests have been used with large numbers of students across the institution. Based on comparative data, we regard the tests as equivalent in difficulty: in 2003 and 2004 large cohorts of first-entry students tested with our post-test achieved mean scores of $68 \%$. In 2005 and 2006 large cohorts wrote our pre-test and the mean score was 69\%. This measure of equivalence is not as rigorous as it might be, and would benefit from more sophisticated analyses (e.g. Van der Walt \& Steyn, 2008, Weideman \& van Slik, 2008, Weideman \& van Slik in press). The overall score shows reliability in the extent that it was consistent across similar populations (consecutive first year intakes at the University of KwaZulu-Natal) (Weideman and van Slik, 2008). However no testing was done of for example performance of these intakes on different items or different sections of the tests.

The discussion that follows focuses on the 2006 intake of students. Students who wrote only one test were excluded from the sample, leaving 241 students who wrote both tests in 2006.

Table 2. Comparing mean performance in the two tests

\begin{tabular}{|l|l|l|lr|}
\hline $\mathbf{N}$ & $\begin{array}{l}\text { Mean pre-test } \\
\text { February 2006 }\end{array}$ & $\begin{array}{l}\text { Mean post-test } \\
\text { October 2006 }\end{array}$ & $\begin{array}{l}\text { Percentage Average } \\
\text { Improvement }\end{array}$ & \\
\hline 239 & $51 \%$ & $61 \%$ & $10 \%$ & \\
\hline
\end{tabular}


For a more detailed comparison of performances student cohorts were divided into three groups based on their performance in the eco-test at the beginning of the year. The first group for 2006 is 79 students with a performance range of $18 \%$ to $44 \%$ on the pre-test. The second group is 79 students with a range of $44 \%$ to $57 \%$ and the third group is 81 students with a range of $58 \%$ to $80 \%$.

Table 3. Comparison of mean performance of three groups $2006(\%)$

\begin{tabular}{|l|l|l|l|l|l|l|l|l|}
\hline 2006 & \multicolumn{3}{|l|}{ Pre-test } & \multicolumn{2}{l|}{ Post-test } & Improvement \\
\hline Group & N & MCQ & Writing & Total & MCQ & Writing & Total $^{*}$ & Total* $^{*}$ \\
\hline Weakest & 79 & 46 & 23 & $\mathbf{3 8}$ & 61 & 37 & $\mathbf{5 1}$ & $\mathbf{1 3 \%}^{\text {13\% }}$ \\
\hline Middle & 79 & 56 & 38 & $\mathbf{5 0}$ & 69 & 49 & $\mathbf{6 1}$ & $\mathbf{1 1 \%}$ \\
\hline Strongest & 81 & 69 & 57 & $\mathbf{6 5}$ & 76 & 61 & $\mathbf{7 0}$ & $\mathbf{5 \%}$ \\
\hline
\end{tabular}

* includes MCQ, written and cloze elements

The MCQ part of the tests assesses students' reading comprehension. The writing part reflects both improvement in reading comprehension and ability to select relevant information and provide a well-organised answer to a focussed question. Table 3 shows that all three groups improved, although the strongest group improved by only $5 \%$ overall. This indicates that they were already quite capable academic readers at the beginning of the course. The weakest group improved by the largest margin (13\%), but many still did not achieve a satisfactory level of proficiency by the end of the course.

The graphs display the improvement in all sections of the tests for all three groups of students. The reading comprehension questions focus on the interpretation of the texts and tap into several reading skills, including what is already known about a topic, ability to interrogate texts and strategies for working out the meaning of unfamiliar vocabulary. Graph 1 shows that the greatest improvement in reading comprehension occurred for the weakest group. The strongest group already had a relatively high score at the beginning of the course. These results imply that the Communication in Science course is least suitable for the strong group, and that their interests would be better served by a more challenging academic literacy course, where readings are longer and more challenging, and more substantial pieces of writing are expected from students. 
Figure 1: Average performance in reading comprehension

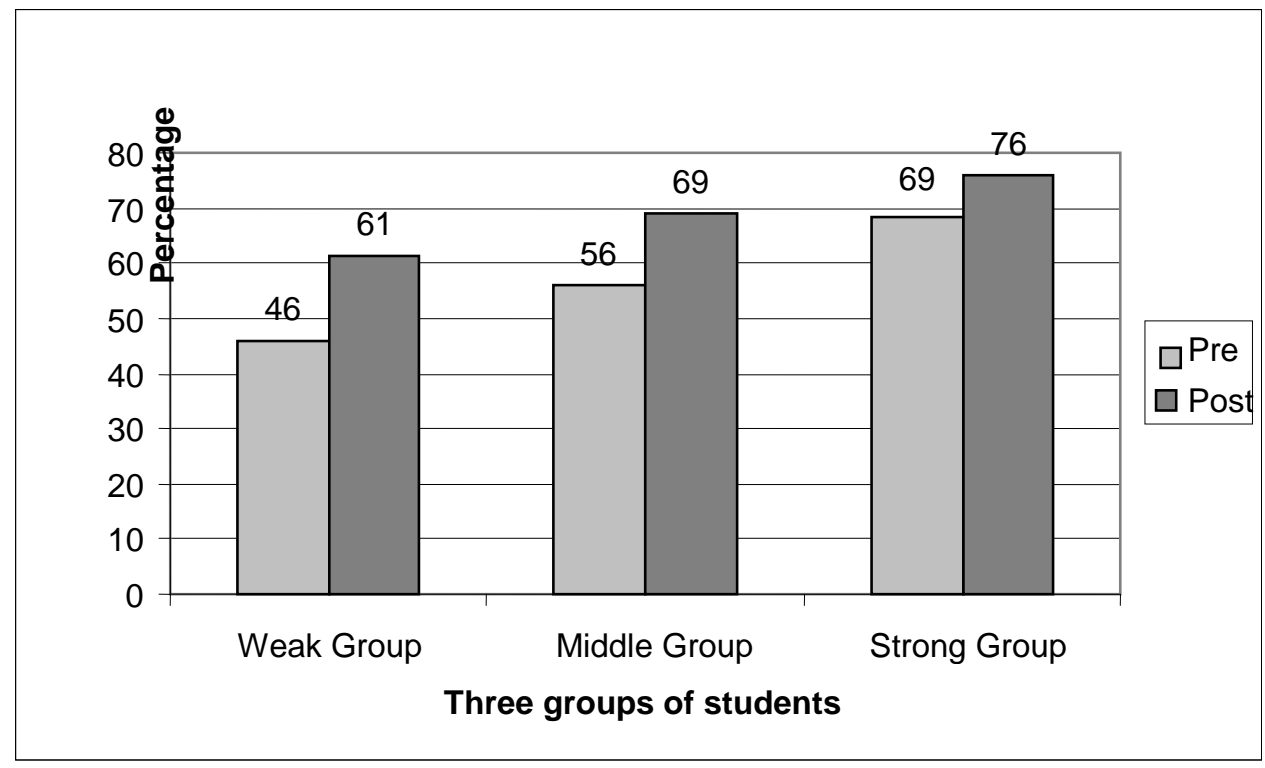

Figure 2: Average performance in writing

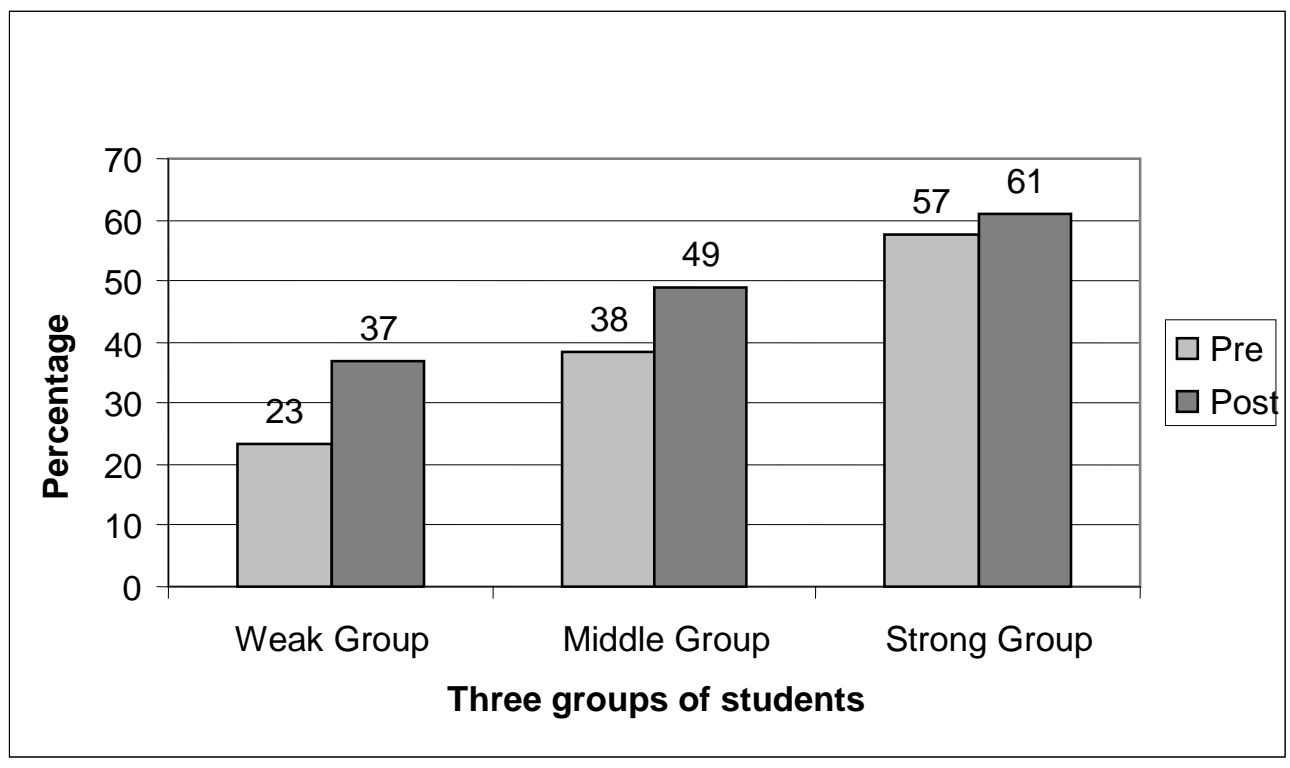

Marks for writing in the tests are assigned not only for retrieval of content from the readings in the test (which assesses comprehension of the reading) but also relevance to the question posed, logical organisation, and also whether or not the language used supports or interferes with the meaning expressed. As Figure 2 shows, all groups show improvement, but the weakest and middle groups do not improve to an acceptable level of proficiency in writing performance. Most of the students in these two groups still do not 'pass' (50\%) the writing competencies. However, given the very substantial improvement that they do make, we certainly do not conclude that the weakest students are too weak to get a degree. We have no evidence that this is the case. Internal monitoring indicates no correlation between performance in the academic literacy module and performance in content subjects in science in the students' first year; (the exception is Biology, a more language-based than mathematics-based discipline). Longitudinal studies should probably be done. At this stage all 
we can say is that probably students would benefit from one more semester of academic literacy to support their progress through their studies.

These tests do not test the specific scientific writing tasks that have been taught during the course (e.g. the laboratory report). Thus the test is not an achievement test for the disciplinespecific writing tasks that students have been taught. However, all three groups improved in the writing task that was given in the tests. In this task students are required to extract information from different texts and express their own opinion. This is an advanced academic competency which is dependent on the ability to interpret a text. It can probably be concluded that improvement in ability to understand and unpack academic text brought about the improvement in this task for all groups.

Comparison of the total results of the two tests for these groups of students shows improvement in performance. The students performed better in both written and MCQ parts of the test both on average and for most individual students. Since the course aims to teach the ability to perform those tasks, especially reading tasks, that are seen as necessary for university study and the tests assess similar abilities, an improvement in the ability to perform these analytical reading tasks is reflected in improved test results.

Figure 3: Average performance on the two tests

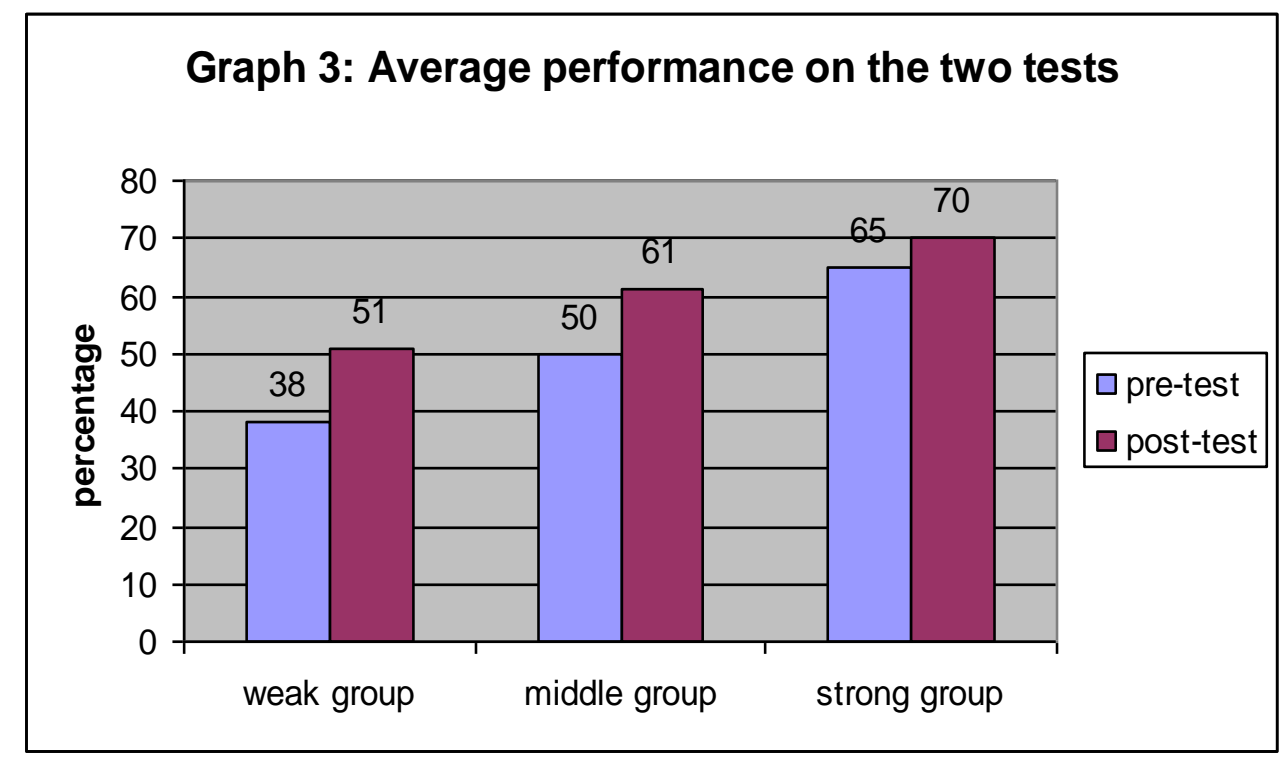

Communication in Science is part of a Science Access programme which aims to develop educationally disadvantaged students to the point where they are able to cope with the demands of a regular science degree. Most other students in the Faculty of Science also wrote the pre-test at the beginning of their first year. It is thus possible to compare the performance (on the post-test) of Communication in Science students after the course with the performance of mainstream Science students in the pre-test. Do they approach the same levels of ability as their mainstream counterparts? 
Table 4: Mean performance of different groups on the Multiple Choice Questions

\begin{tabular}{|l|l|l|l|}
\hline & N & $\begin{array}{l}\text { Pre-test MCQ } \\
\text { February 2006 }\end{array}$ & $\begin{array}{l}\text { Post-test MCQ } \\
\text { October 2006 }\end{array}$ \\
\hline Mainstream science students & 434 & $\mathbf{7 7 \%}$ & \\
\hline Communication in Science (whole group) & 241 & $57 \%$ & $\mathbf{6 9 \%}$ \\
\hline Communication in Science Weak group & 79 & $46 \%$ & $61 \%$ \\
\hline Communication in Science Middle group & 79 & $56 \%$ & $\mathbf{6 9 \%}$ \\
\hline Communication in Science Strong group & 81 & $70 \%$ & $\mathbf{7 6 \%}$ \\
\hline
\end{tabular}

Since the mainstream students wrote only the multiple choice part of the test, performance in the multiple choice questions only can be compared. Table 4 below shows that at the beginning of the year the Communication in Science students performed much worse than the mainstream students. This is to be expected since the Access students were all from educationally disadvantaged schools, had lower matriculation symbols than the mainstream students, and, importantly, they are all English L2 students, while the majority of mainstream students are first language speakers of English. At the end of the course, the strongest group achieved a mean of $76 \%$ in the MCQ's in their test compared to the mainstream students' initial mean of $77 \%$. The middle group also approach the level at which many main stream students performed.

Although improvement was probably the result of the intensive reading training in Communication in Science, it is hard to exclude other factors that could contribute to the improvement. Exposure to English in general had been more extensive for most of the students than ever before in their lives. They had been in a largely English environment for about eight months by the time they wrote the second test. Their other subjects were taught in English and they were surrounded by students of many linguistic backgrounds, who use English as lingua franca in general and academic communication. However, this environment is more likely to contribute to Basic Interpersonal Communication (Cummins \& Swain, 1986) rather than the specific Cognitive Academic Language Proficiency (CALP) that is the goal of Communication in Science. Exposure to academic English in their other courses may have contributed to improvement in CALP, but as content rather than academic literacy is the goal of such courses, it is not easy to measure their contribution. Students had also had much more experience in university tests by the time of the second test. There was probably also less stress at the time of the second test, since the first was written in the stressful first week at university. Nevertheless, the improvement in their ability to read and respond to academic texts is marked enough to assume that Communication in Science contributed to their improvement.

\section{STUDENT EVALUATION OF COMMUNICATION IN SCIENCE AT THE END OF THE COURSE}

To evaluate the effectiveness of Communication in Science we used student evaluation to triangulate our findings about improvement in performance. At the end of the 2006 academic year, 170 Communication in Science students responded anonymously to a questionnaire probing their perceptions of the genres and tasks taught and assessed. Questions focused on knowledge acquired in the course and enjoyment of the course (very enjoyable, OK, hated it). The respondents ticked an option of their choice and additional comments were optional. Table 5 summarises responses. 
Table 5: Student Evaluation of Communication in Science October 2006

\begin{tabular}{|l|l|l|l||l|l|l|}
\hline $\mathrm{N}=170$ students & $\begin{array}{l}\text { Learnt } \\
\text { a lot }\end{array}$ & $\begin{array}{l}\text { learnt } \\
\text { a little }\end{array}$ & $\begin{array}{l}\text { learnt } \\
\text { nothing }\end{array}$ & $\begin{array}{l}\text { Very } \\
\text { enjoyable }\end{array}$ & OK & Hated it \\
\hline Readings during the course & $90 \%$ & $10 \%$ & $0 \%$ & $25 \%$ & $69 \%$ & $6 \%$ \\
\hline Questions at the end of readings & $70 \%$ & $25 \%$ & $5 \%$ & $29 \%$ & $61 \%$ & $10 \%$ \\
\hline Writing during the course & $81 \%$ & $18 \%$ & $1 \%$ & $20 \%$ & $63 \%$ & $17 \%$ \\
\hline Writing essays & $82 \%$ & $16 \%$ & $2 \%$ & $26 \%$ & $46 \%$ & $28 \%$ \\
\hline Writing Reports & $75 \%$ & $20 \%$ & $5 \%$ & $26 \%$ & $47 \%$ & $28 \%$ \\
\hline Chance to do 2 drafts of assignment & $72 \%$ & $26 \%$ & $3 \%$ & $30 \%$ & $51 \%$ & $19 \%$ \\
\hline Class discussions & $73 \%$ & $21 \%$ & $6 \%$ & $57 \%$ & $35 \%$ & $8 \%$ \\
\hline $\begin{array}{l}\text { Average responses for the 7 } \\
\text { individual topics during the year }\end{array}$ & $69 \%$ & $26 \%$ & $5 \%$ & $45 \%$ & $40 \%$ & $14 \%$ \\
\hline Referencing & $89 \%$ & $10 \%$ & $1 \%$ & $36 \%$ & $43 \%$ & $20 \%$ \\
\hline
\end{tabular}

As Table 5 indicates, $90 \%$ of the students stated that they had learnt a lot from the readings. The fact that $69 \%$ of the respondents found the readings to be ' $O K$ ' and $25 \%$ claim to have enjoyed the readings indicates that the materials selected were acceptable in content to the students and probably level-appropriate.

In commenting on how much they learnt from the readings during the course it is likely that students were commenting on their acquisition of content knowledge rather than reading competence, and we therefore probed perceived improvement in reading comprehension by asking how much they learnt from the accompanying comprehension and vocabulary questions. $70 \%$ of the students felt they had learnt a lot from these, and $29 \%$ actually enjoyed the questions. Some respondents claimed to have learnt more from the questions than from the readings. This suggests that students see the benefit of strategies that assist them in stopping to think about the reading, to make connections with existing frames of reference and to work out unknown vocabulary.

The essay, laboratory report and a poster comprise the written component of the course. In the process, students are taught writing techniques such as summarising and paraphrasing. The data show that $82 \%$ of the respondents reported learning a lot from the essay; (one wrote: ' $I$ had no idea how to write an essay when I first arrived now I am one of the best'); a relatively high percentage (75\%) reported that they benefited from report writing. However, 28\% claimed to have hated both these genres, reflecting the difficulty students experience in learning to organise their ideas in writing. Some responses are: 'I hated writing essays because I always failed them' or 'There was too much writing for the course and I felt pressurized'. Positive responses include 'taught me how to summarize' or 'I gained a skill in reports that I could use in Physics too'

Students benefited from the drafting process, used to improve writing competency: $72 \%$ saw the opportunity to submit two drafts as useful while only $3 \%$ claimed to have learnt nothing at all. Writing is a tedious activity for many students, and the fact that $30 \%$ derived enjoyment is gratifying. These comments reflect the feelings of the $19 \%$ who hated the drafting process: 'takes up too much time' or 'It was hard to correct the drafts myself'. These comments indicate the difficulties students experience in acquiring academic literacy. Positive comments include: 'Drafts gave a chance to get better marks'. The greater likelihood of students' attending to tutors' written comments because of the promise of improved marks is one benefit of the drafting process. 
Seventy three per cent indicated that they learnt a lot from class discussions, and this element of the course had the highest rates of enjoyment (57\%). The 8\% (13 students) who hated class discussions may include those students who, right up to the end of the year, had to be coaxed to contribute to class discussions. However, as the year progressed and confidence developed, the majority of students responded favourably to class discussions.

The findings reveal that students view their acquisition of referencing conventions as successful: $89 \%$ believed that they learnt a lot. The comments reflecting positive responses to learning referencing 'It helps us in many modules' indicate an insight into the need to transfer these skills to assignments in other courses. 'It taught me not to take credit for something I did not do' indicates an understanding of one of the key values of the discourse community. One student even claimed to be 'a master for referencing now thanks to Comm Science'. These perceptions are supported by positive reports by tutors to students' use of the conventions in the latter part of the year. This is a quite significant since referencing is an integral part of academic writing, and one that students struggle to acquire.

Overall, students appear to have perceived the course as beneficial, and relevant. Although enjoyment levels are acceptable, with few actually hating the various aspects of the course, students were more positive about how much they learnt (90\% viewed themselves as learning a lot from the readings and $81 \%$ from the writing done) than about how much they enjoyed the course. This is likely to be because the course material is content-based, and perceived by students to be relevant to their science courses.

\section{THE EFFECTIVENESS OF THE MODULE ACCORDING TO PREVIOUS STUDENTS.}

As a third measure of the effectiveness of the course past students were asked by email: Since completing the Communication course, in what ways have the skills you have learnt in Communication in Science been useful to you? About 30 students out of about 380 students surveyed responded ${ }^{1}$. It is possible that those who did respond were not a representative sample of the 300; they may have responded partially because they had more positive attitudes or because they were the more successful students at university. However, the respondents were not markedly more positive than students responding to the end of course evaluation. Of those who did respond, all but two indicated the benefit they derived from the course and acknowledged the value of using the skills acquired in their current direction of study. The respondents are currently engaged in a wide range of degrees in science, as well as degrees in other faculties such as Engineering, Health Science and Medicine.

Some respondents made references to their background of disadvantaged education and attribute their development and confidence at coping with a second language: 'Me, as a student who comes from a disadvantaged school, we did have a chance to practice how to speak in front of people but Communication in Science took me further ... it is really important to us'; 'It developed my skills in grammar since English is not my first language.' The benefit of the course in equipping students to function easily in the academic world is apparent in the following response: 'It helped me mostly in communication with lecturers because we all know that it is difficult to speak in other languages we are not familiar with.'

Students viewed Communication as teaching 'us how to write a logical essay'; giving 'the skills and knowledge of communicating through writing' and being able to 'correct my writing beforehand' and 'analyse test questions.' Apart from providing past students with a 
scaffold for writing, students report that the course played a significant role in strengthening their abilities to deliver oral presentations: 'Communication developed my presentation skills.' The responses received indicate that some former students continue to refer to the course manual two years later: 'Sometimes I go back to my notes and read more'; 'I still refer to it sometimes for its good guidance).

Students referred to literacies taken for granted in their mainstream studies: 'No one will show you how to do graphs but from your knowledge you handle it and show other students'; 'In mainstream they don't teach you how to write a report' and 'It was nice to get two chances for submission of work as we do not get this in mainstream.')

Negative comment came from one respondent who reported stress at having to make a scientific poster, the thought of which made him feel that his 'head is about to burst into flames'. This shows the difficulties students experience in acquiring academic literacy. Although the course has been successful for many students, there are some who despite having been enrolled in academic intervention courses, still experience problems with literacy skills. This is supported by the discussion above of students' performance in the initial and final tests, which indicates that the weakest third of the students are still not reading and writing at the level required for academic study.

Nevertheless, the overall impression drawn from the responses from past students is that the course is beneficial in terms of the teaching of skills relating to the scientific genres. It also helped students grasp reference techniques, edit their work and gain confidence in oral presentations. It is these skills that the students are required to use in their present studies.

\section{CONCLUSION}

A time may come when the need for academic literacy in South African universities will diminish and consequently become less prominent and extensive than at present. This would depend on a greater degree of fit between school and university in terms of academic literacy development, when most South African schools are able to foster the development of written literacy to a much greater degree than is presently the case. Until this revolution in primary and secondary schooling occurs, however, academic literacy courses, of which Communication in Science represents one kind, will remain indispensable. Our measures of the effectiveness of the course indicate that as evaluated against the objective measure of equivalent tests of academic reading and writing, and against the more subjective measure of student perceptions of its value, Communication in Science does appear have had some success in assisting students to acquire the literacies essential for success in academic study. Academic literacy is not, however, something that we either have or do not have, but rather consists of a range of abilities and values that we have acquired to a greater or lesser degree. After two semesters, about a third of the students registered for the Communication in Science course appear to be on a par in terms of academic literacy with entry level students accepted directly into the Science Faculty, as measured by the standardised test used for selection. A further third appear to have reading abilities which will probably meet their needs as science students, although their writing abilities remain weak. A final third, although they have made the biggest improvement in both reading and writing, remain unacceptably weak in writing and not very strong in reading; they should probably be directed to do one or two further semesters in an academic literacy course which has an emphasis on writing. 
Failing this, a level of assistance needs to be in-built at first year level, either in the way described in Jacobs (2005), or as core content courses into which a high level of literacy work is included as in Goodier \& Parkinson (2005) and Butler \& van Dyk (2005). Rather than removing literacy work as far as possible from first year courses, departments need to employ tutors with competencies in both the discipline and in academic literacy. Mainstream lecturing staff need to build literacy work (such as reading assignments, essays and reports summaries) into their offerings and be prepared to scaffold student execution of these.

\section{END NOTE}

${ }^{1}$ These 380 were all the students from the 2005 and 2006 cohorts who were still registered at the university (about $60 \%$ of the original cohort).

\section{ACKNOWLEDGMENT}

We wish to thank the three anonymous reviewers of this article for the valuable input they provided.

\section{REFERENCES}

ANTHONISSEN, C. 2006. On determining what counts while counting: Aspects of language testing where diversity is the standard. Per Linguam, 22(1):39-54.

KIRKWOOD, T. 2007. Reading for a foundation: Why SFP students struggle and how scaffolding can help. Unpublished MA thesis, University of KwaZulu-Natal.

BRAINE, G. 1989. Writing in science and technology: An analysis of assignments from ten undergraduate courses. English for Specific Purposes, 8(1):3-15.

BUTLER, HG \& VAN DYK, TJ. 2004. An academic language intervention for first year engineering students. Southern African Linguistics and Applied Language Studies, 22 $(1 \& 2): 1-8$

CARRELL, PL \& JC EISTERHOLD. 1988. Schema theory and ESL reading pedagogy. In Carrel PL, J Devine \& D Eskey. (Eds), Interactive Approaches to Second Language Reading. New York: Cambridge University Press.260-277.

CLARENCE-FINCHAM, J. (2000). Cummins' contribution to the understanding of language learning and achievement at school. In Inglis, M, C Thomson \& A Macdonald. 2000. Language in learning and teaching (LILT). Pietermaritzburg: University of Natal Press. 141-145.

CUMMINS, J \& M SWAIN. 1986. Bilingualism in education. London: Longman.

DE KADT, E \& N MATHONSI. 2003. Writing in English with an 'African voice': Ownership identity and learning. Journal for Language Teaching. 37(1): 92-102.

DONATO, R. 1994. Collective scaffolding in second language learning. In Lantolf, JP \& G Appel (Eds), Vygotskian approaches to second language research. Norwood: Ablex.3356.

GOODIER, C \& J PARKINSON. 2005. Discipline-based academic literacy in two contexts. SAALT Journal for Language Teaching, 39(1): 66-79. 
GRABE, W. 1988. Reassessing the term 'interactive'. In Carrel PL, J Devine \& D Eskey (Eds), Interactive approaches to second language reading. New York: Cambridge University Press.56-69.

HENNING, E, A MAMIANE, \& M PHEME. 2001. Entering the academy as the 'other': Writing composition and the bridge to the discourse community. South African Journal of Higher Education, 15(1):109-128.

HENNING, E \& W VAN RENSBURG. 2002. Academic development in writing composition: Beyond the limitations of a functionalist and pragmatic curriculum. Journal for Language Teaching, 36(1):82-90.

HUTCHINGS, C. 2005. Aspects of students' learning that affect control of their texts: The writing centre's experience. South African Journal of Higher Education, 19(4):715-734.

JACKSON, L, W MEYER \& J PARKINSON. 2006. The writing tasks and reading assigned to undergraduate science students at a South African University. English for Specific Purposes, 25:260-281.

JACOBS, C. 2005. Teaching students to be literate in Engineering: Whose job is it anyway? Journal of Engineering Design and Technology, 102-108.

KIRKWOOD, T. 2007. Reading for a foundation: Why SFP students struggle and how scaffolding can help. Unpublished MA thesis, University of KwaZulu-Natal.

LEMKE, JL. 1990. Talking science: Language, learning and values. Norwood, NJ: Ablex.

MABOKELA, RO. 1998. The evolution of admission and retention policies at an historically white South African University. Journal of Negro Education. 66(4):423-433.

MERCER, N. 1995. The guided construction of knowledge. Talk amongst teachers and learners. Clevedon: Multilingual Matters.

MULLIS, I, M MARTIN, A KENNEDY, \& P FOY. 2007. PIRLS 2006 International report: IEA's progress in international reading literacy study in primary schools in 40 countries. Boston: TIMMS \& PIRLS International Study Centre, Boston College.

PARKINSON, J. 2000. Acquiring scientific literacy through content and genre. English for Specific Purposes, 19:369-387.

PARKINSON, J, L JACKSON, T KIRKWOOD \& V PADAYACHEE. 2007. A scaffolded reading and writing course for foundation level science students. English for Specific Purposes, 26:443-461.

PIENAAR, C. 2005. Shared assessment: Empowering student writers. Language Matters, 36(2):193-204.

PILE, K \& A SMYTHE. 1999. Language in the human and social science classroom project. In Taylor, N \& P Vinjevold (Eds), Getting learning right. Report of the President's Education Initiative Research Project. Witwatersrand: Joint Education Trust.138-191. 
PRETORIUS EJ. 2002. Reading and Applied Linguistics - a deafening silence? Southern African Linguistics and Applied Language Studies, 20:91-103.

PRETORIUS, EJ \& MP MATCHET. 2004a. Literacy and disadvantage: Learners' achievements in early primary school years. Africa Education Review, 1(1):128-146.

PRETORIUS, EJ \& MP MATCHET. 2004b. Socio-educational accomplishment of literacy advancement in disadvantaged schools. Journal for Language Teaching, 38(1):45-62.

PROBYN, M. 2006. Language and learning science in South Africa. Language and Education, 20(5):391-414.

ROSE, D, L LUI-CHIVIZHE, A MCKNIGHT \& A SMITH. 2003. Scaffolding academic reading and writing at the Koori Centre. Australian Journal of Indigenous Education, 32: 41-49.

STARFIELD, S. 1994. Language, cognition and ESL literacy. TESOL Quarterly. 28(1):1769.

STREET, B. 1984. Literacy in theory and practice. Cambridge: Cambridge University Press.

STREET, B. 1993. Cross-cultural approaches to literacy. Cambridge: Cambridge University Press.

TAYLOR, N \& P VINJEVOLD. 1999. Teaching and learning in South African schools. In Taylor, N \& P Vinjevold (Eds), Getting learning right. Report of the President's Education Initiative Research Project. Witwatersrand: Joint Education Trust.138-191.

THOMSON, C. 2005. Towards an integration of a pedagogical and political project: The use of the genre approach in academic literacy development. South African Journal of Higher Education, 19(1):20-30.

UNSWORTH, L. 1997. Scaffolded reading of Science explanations: Accessing the grammatical and visual forms of specialized knowledge. UKRA. Oxford: Blackwell Publishers.

VAN DER SLIK, F \& A WEIDEMAN. 2005. The refinement of a test of academic literacy. Per Linguam, 21(1):23-35

VAN DER WALT, JL \& HS STEYN JNR. 2008. Pragmatic validation of a test of academic literacy at tertiary level. Ensovoorts, 11(2):138-153.

VAN DYK, TJ. 2005. Towards providing effective academic literacy intervention. Per Linguam, 25(2):38-51.

VAN WYK, A. 2002. A university bridging course focusing on academic reading and writing skills. Journal for Language Teaching, 36(3-4):220-232. 
WEIDEMAN, A. 2003. Assessing and developing academic literacy. Per Linguam, 19(1\&2): 55-65.

WEIDEMAN, A. \& F. VAN DER SLIK. 2008. The stability of test design: measuring difference in performance across several administrations of a test of academic literacy. Acta Academica 40(1):161-182.

WEIDEMAN, A. \& F. VAN DER SLIK. In Press. Testing academic literacy over time: Is the academic literacy of first year students deteriorating? Ensovoorts.

YELD, N \& W HAECK. 1997. Educational histories and academic potential: Can tests deliver? Assessment and Evaluation in Higher Education, 22(1):5-16.

YELD, N. 2003. Academic literacy and numeracy profiles. (2001/2003 entry years). In SAUVCA: Into Higher Education: Perspectives on entry thresholds and enrolment systems. Pretoria: SAUVCA.21-48.

\section{BIOGRAPHIC NOTE}

Jean Parkinson teaches academic literacy in the Science Faculty at the University of KwaZulu-Natal. Her research interests include language teaching and literacy acquisition and science discourse. Email: PARKINSON@ukzn.ac.za

Leonora Jackson is coordinator of entrance testing at the University of KwaZulu-Natal. She has experience in teaching English for Academic Purposes in various faculties of UKZN. She is involved in institutional research on testing as selection tool and research into the assessment of academic writing.

Tamlin Kirkwood is a lecturer in the Department of Applied Language Studies on the Pietermaritzburg campus of the University of KwaZulu-Natal. Her research interests in the field of Educational Linguistics focus on reading proficiency in the development of academic literacy, particularly in the disciplines of science.

Vasanthie Padayachee is a senior tutor in the Science Faculty at the University of KwaZulu-Natal. She currently teaches Communication in Science and has a literature and teaching background. 


\section{APPENDIX 1: STUDENT EVALUATION OF THE COURSE}

\section{Communication in Science}

\section{Course Evaluation: October 2006}

Please help improve the Communication in Science module. Give your opinion of the following aspects of the module by ticking the blocks that best match how you feel.

\begin{tabular}{|c|c|c|c|c|c|c|c|}
\hline & \multicolumn{3}{|c|}{ How much did you learn? } & \multicolumn{3}{|c|}{ How enjoyable was it? } & \multirow{2}{*}{$\begin{array}{l}\text { Your comment on this } \\
\text { aspect of the course: }\end{array}$} \\
\hline Reading we did for the course & $\begin{array}{c}\text { learnt a } \\
\text { lot }\end{array}$ & $\begin{array}{c}\text { learnt a } \\
\text { bit }\end{array}$ & $\begin{array}{c}\text { learnt } \\
\text { nothing }\end{array}$ & $\begin{array}{c}\text { Very } \\
\text { enjoyable }\end{array}$ & $\mathrm{OK}$ & Hated it & \\
\hline Writing we did for the course & $\begin{array}{c}\text { learnt a } \\
\text { lot }\end{array}$ & $\begin{array}{c}\text { learnt a } \\
\text { bit }\end{array}$ & $\begin{array}{c}\text { learnt } \\
\text { nothing }\end{array}$ & $\begin{array}{c}\text { Very } \\
\text { enjoyable }\end{array}$ & $\mathrm{OK}$ & Hated it & \\
\hline $\begin{array}{l}\text { Opportunity to submit two } \\
\text { drafts of assignments }\end{array}$ & $\begin{array}{c}\text { learnt a } \\
\text { lot }\end{array}$ & $\begin{array}{c}\text { learnt a } \\
\text { bit }\end{array}$ & $\begin{array}{c}\text { learnt } \\
\text { nothing }\end{array}$ & $\begin{array}{c}\text { Very } \\
\text { enjoyable }\end{array}$ & $\mathrm{OK}$ & Hated it & \\
\hline $\begin{array}{l}\text { Class discussion with } \\
\text { colleagues }\end{array}$ & $\begin{array}{c}\text { learnt a } \\
\text { lot }\end{array}$ & $\begin{array}{c}\text { learnt a } \\
\text { bit }\end{array}$ & $\begin{array}{c}\text { learnt } \\
\text { nothing }\end{array}$ & $\begin{array}{c}\text { Very } \\
\text { enjoyable }\end{array}$ & $\mathrm{OK}$ & Hated it & \\
\hline $\begin{array}{l}\text { Questions at the end of each } \\
\text { reading }\end{array}$ & $\begin{array}{c}\text { learnt a } \\
\text { lot }\end{array}$ & $\begin{array}{c}\text { learnt a } \\
\text { bit }\end{array}$ & $\begin{array}{c}\text { learnt } \\
\text { nothing }\end{array}$ & $\begin{array}{c}\text { Very } \\
\text { enjoyable }\end{array}$ & $\mathrm{OK}$ & Hated it & \\
\hline Essay on Malaria & $\begin{array}{c}\text { learnt a } \\
\text { lot }\end{array}$ & $\begin{array}{c}\text { learnt a } \\
\text { bit }\end{array}$ & $\begin{array}{c}\text { learnt } \\
\text { nothing }\end{array}$ & $\begin{array}{c}\text { Very } \\
\text { enjoyable }\end{array}$ & $\mathrm{OK}$ & Hated it & \\
\hline $\begin{array}{l}\text { Poster on Euthanasia/ Animal } \\
\text { Experimentation }\end{array}$ & $\begin{array}{c}\text { learnt a } \\
\text { lot }\end{array}$ & $\begin{array}{c}\text { learnt a } \\
\text { bit }\end{array}$ & $\begin{array}{c}\text { learnt } \\
\text { nothing }\end{array}$ & $\begin{array}{c}\text { Very } \\
\text { enjoyable }\end{array}$ & $\mathrm{OK}$ & Hated it & \\
\hline Report on Electromagnetism & $\begin{array}{c}\text { learnt a } \\
\text { lot }\end{array}$ & $\begin{array}{c}\text { learnt a } \\
\text { bit }\end{array}$ & $\begin{array}{c}\text { learnt } \\
\text { nothing }\end{array}$ & $\begin{array}{c}\text { Very } \\
\text { enjoyable }\end{array}$ & $\mathrm{OK}$ & Hated it & \\
\hline
\end{tabular}

1. Please comment on the questions that we do at the end of each reading. Did you find them to be helpful? Did you find them to be interesting? Did they assist you in understanding the readings?

Please delete what is not applicable:

2. I find that the lecturer's comments on drafts are useful/not useful

3. I find that there are enough/not enough lecturer's comments on the draft

4. I have become a faster reader during this year: yes/no

5. I understand what I read better than I did at the beginning of the year: yes/no

6. Please comment on the form of assessment (assignments and test) in Communication in Science:

7. Other comments on the course: 